\title{
On the Development Community of Foreign Language Teachers in Colleges and Universities Based on the Internet
}

\author{
Juan $\mathrm{Liu}^{1}$ Kun $\mathrm{Ni}^{2 *}$ \\ ${ }^{1,2}$ Nanchang JiaoTong Institute, Nanchang, Jiangxi, 330100, China
}

\begin{abstract}
With the continuous development and progress of science and technology in China, more and more schools and teachers are beginning to combine the "Internet" technology for teaching. Under the background of the Internet, teachers should strive to create a relaxed, equal and democratic atmosphere in the classroom, so that they can impart knowledge to students well and students can master it better. In campus, both tacit knowledge and explicit knowledge need teachers to keep pace with the times, give full play to the advantages of computer and Internet, and effectively impart knowledge to students. By the combination of "Internet" and foreign language teaching in colleges and universities, the community teaching mode has made the foreign language curriculum in colleges and universities better developed. Under the background of "Internet ", the community construction of teachers' professional development makes teachers' professional development closely related to the Internet, which is the inevitable trend of teachers' professional development.
\end{abstract}

\section{Introduction}

With the rapid development of science and technology, the Internet era has come. Due to the constant attention of our country to education, the professional development of teachers has been paid more and more attention. In recent years, the research on foreign language teachers and their development in our country has just made a new discovery, and the development of foreign language teachers and their development has long time ago, and our country is much later at the starting point. In the early years, the requirements for teachers' professional development in our country are "strengthening in-service education ", actively carrying out educational and teaching activities, and teachers' self-study. This paper analyzes the characteristics and functions of teacher professional development community under the background of "Internet ", and discusses the construction ideas of teacher professional development community from many angles, so as to help foreign language teachers in colleges and universities get better development.

\section{Characteristics of Teacher Professional Development Community in the Internet Environment}

Now is the Internet science and technology era, Internet users are increasing, many industries have changed, stores have changed to online shopping, then school teaching should also conform to the times, change teaching methods, group interaction, network integration of the new teaching model[1]. The change of teaching mode also means that teachers' professional requirements are also high, teachers also need to continue to learn, continuous progress. Now implemented, based on the network platform under a learning community. This kind of teacher learning community, first of all, has certain stability, does not have too much tedious procedure, also does not need other redundant equipment, does not need any technology, may complete by oneself. Under the organization of leadership or teaching team, training and learning together, personnel also have stability, join excellent teachers and experts, everyone participate. In this way, the organization of training activities, there are focused goals and key themes, conducive to teachers' professional learning. Secondly, it is also mixed. This kind of teacher professional learning community can not only learn together, teach and research together, but also watch the teaching video in the network to study together, forming the form of "Internet teacher teaching and research ", which is more unique. Moreover, teachers can choose whether to participate in the training or choose different training courses. Thirdly, it is also interactive, teachers' professional community learning, so that teachers and teachers can communicate and discuss each other, learn from each other's advantages in teaching, and even teachers in different places can participate in the discussion. Also can carry on face-to-face communication in the computer screen, achieves the information sharing. This is unimaginable in the past, but now we can easily communicate through the Internet, and even learn more and better knowledge. Finally, there are many problems encountered in teaching in the study

\footnotetext{
*Corresponding author's e-mail: 739960103@qq.com
} 
of teachers' professional community. Some of these problems can be solved by individual teachers, others need to be discussed and solved together by the whole group of teachers. The group can analyze the problem more comprehensively. Teachers in the learning community, each teacher can be promoted. New teachers can learn some professional knowledge and skills, and experienced teachers can learn teaching methods and experiences from excellent teachers. Internet era is a big data era, information age, in the teacher community, the process of learning and the results of learning can be displayed through data, in the process of teaching and research activities for data recording, storage, analysis[2], later through these data analysis for decision-making, find a better way.

\section{Role of Learning Community of Foreign Language Teachers in Colleges and Universities Based on Internet}

\subsection{To enhance interaction among foreign language teachers}

Each university has its own teaching and research team, usually the members of the teaching and research team

TABLE I. DIFFICULTIES IN THE REFORM AND COMPARISON OF QQ AND WECHAT LAUNCHES BETWEEN 2015 TO 2019

\begin{tabular}{|c|c|c|c|c|c|}
\hline \multicolumn{7}{|c|}{ Comparison of QQ and WeChat launches ,2015-2019 } \\
\hline age & $\mathbf{2 0 1 5}$ & $\mathbf{2 0 1 6}$ & $\mathbf{2 0 1 7}$ & $\mathbf{2 0 1 8}$ & $\mathbf{2 0 1 9}$ \\
\hline QQ (Billions) & 15977.2 & 15673.7 & 12457.0 & 13141.2 & 14502.2 \\
\hline $\begin{array}{c}\text { Wechat } \\
\text { (Billions) }\end{array}$ & 41106.9 & 46101.0 & 46573.2 & 45208.3 & 44332.3 \\
\hline
\end{tabular}

\subsection{Open up the way of teachers' teaching and research and learning channels}

Foreign language teachers in colleges and universities can learn through the "Internet ", and can also watch teaching videos on the Internet through the network platform, carry out research, and complete the study of teaching skills. For example, teachers can find some quality class videos on some websites, or teaching videos of excellent teachers. After watching, they have any ideas and questions, and can also find some like-minded teachers to discuss together in time. The development of Internet technology, the impact on the cause of education is also very important.

\subsection{Promoting complementarity between experienced and new teachers}

In the education industry, there are new teachers, of course, there will be some senior teachers, whether new teachers or old teachers have their own advantages and disadvantages. Qualified teachers, they have rich teaching experience and rich teaching resources. Generally speaking, qualified teachers are the main are fixed, so the members of the teaching and research team communicate most. However, it is not ruled out that some teachers are shy or not very good at expression, so there will be a lack of communication between members, and the lack of communication will lead to teaching problems can not be solved very well. Therefore, using the Internet platform, teachers can communicate online to avoid face-to-face embarrassment and shyness. At the same time, there are language translation functions in the network, teachers in different countries, or teachers with no language can also communicate, avoiding unnecessary trouble caused by language barriers. For example, now more social software QQ, WeChat, Weibo and so on, all professions, all ages are used. Or network communication has changed the traditional way of communication, broken the traditional binding force, let the communication between teachers become more and more convenient, free, can let teachers better say their inner thoughts. For a long time, teachers can put down some mustard in their hearts, focus on teaching, can quickly find their shortcomings and shortcomings[3], and then timely correction. teachers in teaching, and often organize some teaching and research activities. But if you encounter some very difficult research projects, it will be a little hard for teachers of a certain age, and some of them may not be able to use Internet technology. This is, new teachers can play their advantage. New foreign language teachers, who often use the Internet in their normal lives and study on the Internet, can be responsible for helping to search for information, and in terms of energy, they will have more advantages than qualified teachers.

\section{Strategies for the Professional Development of Foreign Language Teachers in Colleges and Universities under the Background of Internet}

With the addition of "Internet ", some great changes have taken place in the education industry. It guides teachers to change, make teachers follow the pace of the times, form a community of professional development of teachers, and realize the integration of teachers and the Internet. Then the model construction of teacher professional development community needs Internet information sharing, team organization, expert guidance, 
online and offline combination, so as to truly realize the construction of teacher professional development community.

\section{1 "Internet" sharing enhances teachers' cognition}

Nowadays, the Internet has been popularized in many places, which is good for some local schools, because they can get the Internet to share information. So in the era of "Internet ", the cognition of teacher professional development community is very necessary for foreign language teachers, understand the concept of teacher professional development community, know the advantages of it, and better join the learning community. The Internet is shared, any resources can be shared through the network, teachers can organize and systematic learning. Teachers have learned the concept and technology of "Internet ", they should understand that education and teaching need innovation, combine with Internet technology to innovate teaching methods, and achieve the diversification of education[4]. Internet has openness and sharing, teaching combined with the Internet also has openness and sharing, online education, flipping classroom, MOOC and so on are the new normal of the "Internet" now. Both teachers and students learn to use the Internet platform to learn and increase their knowledge reserves. The Internet integrates all resources, no matter any industry, any time, can be queried through the Internet. As a worker in education, teachers are the leaders of education. They should be familiar with Internet technology, and learn to use Internet technology first, so that education and the Internet can be better combined. Realize "Internet" teacher professional development form.

\subsection{Forming the Professional Development Community of Teachers with Internet Elements}

The Internet includes many elements, which are the key to the construction of teachers' professional development community, mobile communication network access, Internet services, mobile communication terminals. Today's most popular mobile communication tool is mobile phones, almost everyone has a mobile phone, whether primary school students or elderly people, will use mobile phones. Mobile phones can download a lot of APP, among them can let people communicate with each other APP, such as WeChat, QQ and so on, which is now the norm, which also provides the foundation for the construction of teachers' professional development community. By using Internet elements, teachers can organize teachers' learning groups, that is, using mobile phones, computers, tablets and other devices as communication tools, and constructing teachers' learning groups, such as QQ groups, WeChat groups, etc., in which they can communicate and discuss any problems in teaching. With the rapid development of "Internet education ", teachers' professional development has more levels, and various learning resources can also meet the needs of different people.

\subsection{Experts as guidance to build a professional development community for teachers}

Teachers' professional development and professional accomplishment can not be separated from the guidance of expert teachers. The guidance of a good famous teacher is very helpful to the development of teachers. Especially the new teachers[5], the training of teachers' professional skills is very necessary when they are just getting started, which can be withdrawn in the later teaching. The guidance of famous teachers is mainly reflected in teaching methods and teachers' professional development direction. Through the guidance of famous teachers, we can find some teaching problems, correct them in time, and learn some better teaching methods from famous teachers. According to the different subjects can be classified learning, major subjects can choose the same subject of famous teachers to learn, but also can create a group of famous teachers to learn, discuss together, timely questions raised, This can solve problems more comprehensively and quickly. The professional development group of teachers led by experts should be based on discipline, experts as the core and teachers as the main body to construct a trinity network learning chain. According to the analysis of typical cases in teaching, famous teachers speak and teachers learn, so that teachers can constantly improve their professional literacy under the encouragement of the external and internal driving forces of learning. This makes the teacher professional development community under the promotion of the Internet more mature.

\subsection{Online and offline integration for sustainable development of the Community of Teachers' Professional Development}

Teacher professional development is a long-term accumulation process, is sustainable development, teachers themselves should be based on the concept of lifelong learning, in the education industry to continue to learn, improve their professional literacy. Teachers' professional development can be carried out through various channels, which can not only study in the teaching team of off-line colleges and universities, participate in the foreign language teaching and research activities in schools, and improve their professional skills You can also search the Internet for videos about foreign language teaching and improve your professional development through online learning. Some problems found on the line should be communicated with the teachers in the online class in time, or the group teachers can be asked in the communication group to discuss and find solutions[6]. After learning, the teacher applies the theory to the actual teaching, see if it is applicable, and then analyze and reflect. This combination of online and offline teaching practice is conducive to the continuous improvement of teachers' professional development level. 


\section{CONCLUSION}

"Internet" provides the train of thought and the foundation for the teacher professional development community, this innovative development has produced the profound influence in the education profession. Now teachers should follow the pace of the times, adapt to the form of "Internet" development, strive to meet the needs of foreign language teachers' professional development community, constantly improve their own professional development level, and make more contributions to education.

\section{ACKNOWLEDGMENT}

This work was supported by The Project of Humanities and Social Sciences of Jiangxi Province.

Funding: Author Liu Juan was supported by the grant from the Project of Humanities and Social Sciences of Jiangxi Province under Grant No. JC20261

\section{REFERENCES}

1. Qin, Y.L. (2017) Construction Mode and Strategy of Teacher Professional Development Community under the Background of Internet[J]. Guangxi Foreign Language Education Science.

2. Li, J. H. (2015) Welcome the Professional Development of Teachers in the Internet Age[J]. Information technology education in primary and secondary schools.

3. Sun, M.H. (2018) On the Development Community of Foreign Language Teachers in Colleges and Universities Based on the Internet[J].Dalian Jiaotong University.

4. Wu, Y. Liu, H. Ren, Y.Q. (2015)"Internet" Campus: A New Stage of Intelligent Campus Construction in Colleges and Universities[J]. Journal of Distance Education.

5. Zhao, J.H. (2010) A Case Study on Promoting Cooperative Development of Urban and Rural Schools with Informatization[J]. Audio-visual education research.

6. Lin, R.Z. (2007) Building a Professional Development Community for Teachers to Improve the Professional Development of Teachers[J]. Educational Theory and Practice. 